NBER WORKING PAPER SERIES

\title{
ASSET ALLOCATION AND RISK ALLOCATION: CAN SOCIAL SECURITY IMPROVE ITS FUTURE SOLVENCY PROBLEM BY INVESTING IN PRIVATE SECURITIES?
}

\author{
Thomas E. MaCurdy \\ John B. Shoven \\ Working Paper 7015 \\ http://www.nber.org/papers/w7015 \\ NATIONAL BUREAU OF ECONOMIC RESEARCH \\ 1050 Massachusetts Avenue \\ Cambridge, MA 02138 \\ March 1999
}

This paper was presented at the NBER Conference on Risk Aspects of Investment Based Social Security Campbell and Martin Feldstein, organizers, January $15^{\text {th }}$ and $16^{\text {th }}, 1999$, Cheeca Lodge, We have benefited from the comments and help of John Campbell, Victor Fuchs, Jim Islamorada, Florida. We have and Steve Zeldes. We would also like to acknowledge the fine research Poterba, Sylvester Schieber, and Ste Zis assistance of Stanford Ph.D. students Davide Lomose of the National Bureau of Economic Research. 1999 by Thomas E. MaCurdy and John B. Shoven. All rights reserved. Short sections of text, not to
exceed two paragraphs, may be quoted without explicit permission provided that full credit, including ${ }^{\odot}$ notice, is given to the source. 
Asset Allocation and Risk Allocation: Can Social Security Improve

Its Future Solvency Problem By Investing In Private Securities?

Thomas E. MaCurdy and John B. Shoven

NBER Working Paper No. 7015

March 1999

JEL No. G11

\section{ABSTRACT}

This paper examines the economics of investing the central trust fund of Social Security in private securities. We note that switching from a policy of having the trust fund invest solely in special issue Treasury bonds to one where some of the portfolio holds common stocks amounts to an asset swap. Such an asset swap does not increase national saving, wealth or GDP. We also show that it is far from a sure thing in terms of improving the finances of the Social Security system. The asset swap is deemed successful if the stock portfolio generates sufficient cash to pay off the interest and principal of the bonds and still have money left over. It is deemed a failure otherwise. By using historical data and a bootstrap statistical technique, we estimate that the exchange of ten or twenty year bonds for a stock portfolio would worsen social security's finances roughly twenty to twentyfive percent of the time. Further, failures are autocorrelated meaning that if the strategy fails one year it is extremely likely to fail the next. Such high failure rates imply that the defined benefit structure of benefits becomes less credible with stocks in the trust fund.

Thomas E. MaCurdy

Department of Economics

Stanford University

Stanford, California 94305

and NBER

tmac@leland.stanford.edu
John B. Shoven

Department of Economics

Stanford University

Stanford, California 94305

and NBER

shoven@leland.stanford.edu 
Asset Allocation and Risk Allocation: Can Social Security Improve Its Future Solvency Problem by Investing In Private Securities?

by

Thomas E. MaCurdy and John B. Shoven

\section{Introduction}

Policymakers widely accept that Social Security faces a long-run solvency problem. The Social Security Trustees publish a 75-year forecast of the OASDI system's finances every year. Since the 1983 amendments the forecast has gotten consistently more ominous. Figure 1 shows the intermediate-assumptions forecast for the Trust Fund balances in 1983, 1985 and 1998.

\section{Figure 1: Three Forecasts of the OASDI Trust Fund Balances}

Billions of current dollars

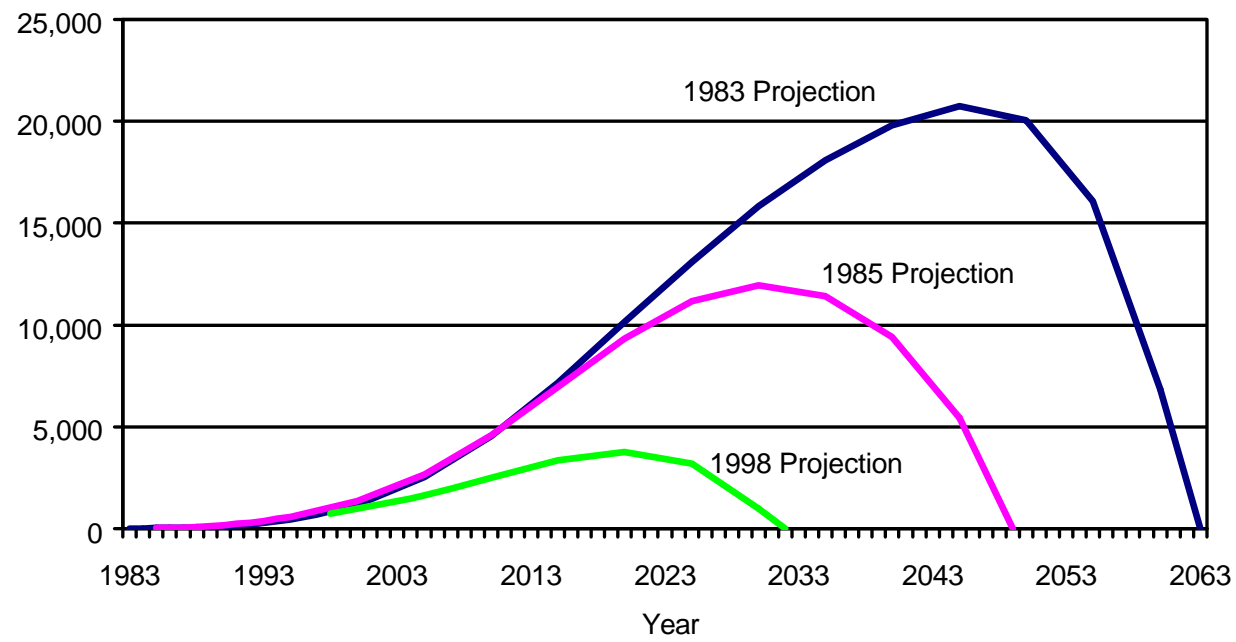

The 1998 Trustees Report has the OASDI Trust Fund completely depleted in 2032 (when the youngest babyboomer, born in 1964, will be 68) rather than the forecast of the depletion date that immediately followed the 1983 Social Security amendments of 2063 (when the same individual will be 99 years old). The 1998 OASDI Trustees Report has as the intermediate or "best guess" forecast that the system's income (not counting net interest income on the special issue bonds 
held in the trust fund) would fall short of its costs beginning in 2013. In 1999, the surplus is expected to be 1.52 percent of covered payroll, but this turns negative in 2013 and by the end of the Trustee's forecasting period (2075) the annual shortfall under the intermediate set of assumptions is forecast to be 6.43 percent of covered payroll. That means that if we operated the system on a strictly pay-as-you-go basis, the payroll tax rate would have to be increased by 6.43 percentage points to achieve balance in 2075. The 2075 OASDI deficit (with the intermediate assumptions forecast) amounts to 4.26 percent of GDP. One way to look at the financial solvency problem of Social Security is that the intermediate forecast is for fourteen years of modest and declining surpluses followed by ever growing deficits as far as the eye can see. Against that we have a relatively small Trust Fund (currently $\$ 760$ billion) which generates roughly $\$ 40$ billion of interest income but which is now forecast to be completely depleted by 2032 as shown in Figure 1. Naturally, the financial situation for OASDI is much worse under the Trustees' high-cost set of assumptions. With them, the date of the OASDI Trust Fund exhaustion is 2022. The date when payroll tax receipts first fall short of benefit payments is 2006 and the eventual shortfall of income to costs in 2075 is 16.04 percent of taxable payroll.

The Social Security Trustees summarize the 75-year outlook for OASDI by computing the long-run actuarial balance. In 1998 the 75-year actuarial balance was in deficit by 2.19 percent of covered payroll with the Trustees' intermediate assumptions. What that means is that if the payroll tax had been immediately increased in 1998 by 2.19 percentage points and the increase was maintained for the next 75 years, then the life of the Trust Fund would have been extended to the 75 year horizon under the intermediate set of economic and demographic assumptions. Even under this hypothetical scenario, the payroll tax proceeds would be less than benefit payments under the currently legislated benefit structure beginning in roughly 2020 . 
Further, the 75-year actuarial balance would last for exactly one year; with every passing year one fewer surplus year would be in the 75-year window and one more deficit one would be included. The immediate payroll tax increase to permanently fix the solvency problem of the current OASDI system would be significantly greater than 2.19 percent. Steven Goss of the Office of the Actuary of the Social Security Administration has estimated that the permanent or open-ended actuarial deficit is 4.7 percent of covered payroll under the intermediate set of assumptions (Goss (1999)).

All of this illustrates the dimensions of the problem of returning the existing OASDI system to long-run solvency. Operating within the existing structure of Social Security, there are only two obvious paths: (1) raise taxes and/or (2) cut benefits. If we take Steven Goss's 4.7 percent of covered payroll figure for the perpetual actuarial deficit, then permanently fixing the finances of the system (under the intermediate set of economic and demographic assumptions) would require immediate tax increases or benefit cuts totaling 38 percent. If these steps are delayed in their implementation, as they almost certainly would be, then the benefit cuts and tax increases would need to be larger. Neither tax increases nor benefit cuts of this magnitude are economically or politically attractive. Naturally, people are looking for a more palatable way out of the Social Security solvency problem.

One natural place to look is the investment returns earned on the trust fund. Currently, the trust fund is exclusively invested in special nonmarketable U.S. government bonds. When these bonds are issued their interest rate is set at the average interest rate of marketable Treasury bonds with a maturity of four years or more. The bonds have one special feature, which offsets their nonmarketability: they are redeemable at par at any time. This feature is not generally available on publicly held bonds and notes with the exception of U.S. Government Savings 
Bonds. The special issue bonds are certainly safe with no price risk and with the principal and interest fully backed by the U.S. government, but Treasury interest rates are somewhat less than what is offered on AAA corporate bonds and trail the average total return earned on common stocks by a wide margin.

The question we address in this paper is whether a significant fraction of the whole solvency problem could reliably be solved by having the Social Security Administration invest the OASDI trust fund in higher yielding private securities. The analysis of MaCurdy and Shoven(1992) suggests such a strategy might yield an improvement in Social Security's

finances. ${ }^{1}$ Of course, there is a more fundamental question regarding whether society as a whole would benefit from this new asset allocation. Another question we address is how risky such a change in the trust fund asset allocation would be and who would bear that risk. Related to this question, we will discuss the feasibility of Social Security delivering a true defined benefit pension program to its participants.

\section{The Proposals}

We focus on two of the reform proposals that rely on investing the central trust fund in higher yielding private securities in order to maintain the general benefit structure of Social Security. However, our analysis is applicable to any plan that attempts to make progress on the solvency of the system by simply reallocating portfolios towards higher yielding securities including the plan outlined by President Clinton in his 1999 State of the Union Address. The two plans of this type that we describe in detail are the "Maintain Benefits" proposal of the 199496 Advisory Council (often referred to as the Bob Ball plan) and the plan offered in the recently published book by Henry Aaron and Robert Reischauer (Aaron \& Reischauer (1998)). Among 
the measures that both of them advocate, the asset reallocation is credited with the largest impact on reducing or eliminating the 75-year actuarial deficit.

The details of the two plans are shown in Table 1. There are many similarities between them. The numbers in the tables come directly from the Aaron and Reischauer book (Table 6-1) and from Volume I of the Report of the 1994-96 Advisory Council on Social Security (Table 1,

Table 1: Contribution of Each Feature of the Aaron/Reischauer Plan and the Maintain Benefits Plan to the 75-Year OASDI Actuarial Deficit (all numbers are \% of covered payroll)

\begin{tabular}{|l|c|c|}
\hline & Aaron/Reischauer Plan & Maintain Benefits Plan \\
\hline $\begin{array}{l}\text { Projected Long-Term Deficit (\% of } \\
\text { covered payroll) }\end{array}$ & 2.19 & 2.17 \\
\hline $\begin{array}{l}\text { Effect of Assumed Changes by BLS in } \\
\text { CPI Measurement }\end{array}$ & -.45 & -.31 \\
\hline $\begin{array}{l}\text { Cover All Newly Hired State and Local } \\
\text { Employees }\end{array}$ & -.21 & -.22 \\
\hline $\begin{array}{l}\text { Increase the number of years in the } \\
\text { AIME Formula from 35 to 38. }\end{array}$ & -.25 \\
\hline $\begin{array}{l}\text { Tax 85 percent of Social Security } \\
\text { Benefits }\end{array}$ & -.36 \\
\hline $\begin{array}{l}\text { Increase the OASDI payroll tax in 2045 } \\
\text { by a combined 1.6 percentage points }\end{array}$ & NA & -.31 \\
\hline $\begin{array}{l}\text { Redirect Revenue for taxation of benefits } \\
\text { from HI to OASDI starting in 2010 }\end{array}$ & -.49 & -.22 \\
\hline $\begin{array}{l}\text { Raise the Normal Retirement Age to } 67 \\
\text { by 2011 and then index further increases } \\
\text { to changes improvements in mortality }\end{array}$ & & NA \\
\hline $\begin{array}{l}\text { Raise the age of early retirement } \\
\text { eligibility to 64 by 2011 and then index } \\
\text { further increases to improvements in } \\
\text { mortality }\end{array}$ & -.23 & NA \\
\hline $\begin{array}{l}\text { Gradually reduce spouse's benefit from } \\
\text { 50\% to 33.33\%. Raise benefits for } \\
\text { surviving spouses to 75\% of couple's } \\
\text { combined benefit }\end{array}$ & -.85 & -.24 \\
\hline $\begin{array}{l}\text { Gradually invest part of the trust fund } \\
\text { assets in private stocks and bonds }\end{array}$ & & NA \\
\hline \begin{tabular}{l}
$75-Y$ Yar Deficit with Plan \\
\hline
\end{tabular} & & \\
\hline
\end{tabular}


Appendix II). The figures are based on estimates of the Office of the Actuary of the Social Security Administration assuming the intermediate alternative II economic and demographic conditions. The numbers for the same action may differ slightly for the two plans since the estimates for the Aaron/Reischauer plan were made roughly two years later than those for the Maintain Benefits plan. Further, the plans differ slightly in how they implement each measure. Even with that said, both proposals have the same goal - to deal with the 75-year actuarial deficit within the context of the current structure of benefits. They both assume that the measurement of the CPI will be changed in ways that lower official inflation and cause the program's costs to grow more slowly. ${ }^{2}$ They both advocate covering all newly hired state and local workers, increasing the number of years included in the AIME formula from 35 to 38, and taxing all Social Security benefits received over and above the employees own actual contributions. Both proposals characterize their changes in the personal income taxation of Social Security benefits as putting them on the same basis as private pension income. However, their plans involve significantly higher taxes than the Schieber-Shoven PSA-2000 plan, which also claims to put Social Security and private pension benefits on the same tax footing (SchieberShoven (1999)). The PSA-2000 plan taxes half of Social Security benefits on the argument that half of Social Security contributions were made with before-tax money (the employer contribution) and half with after-tax dollars (the employee contribution). Essentially, SchieberShoven's plan would have half of the contributions treated like a Roth IRA (after-tax contributions with tax-free withdrawals) and half like a regular IRA (before-tax contributions with taxable withdrawals). In contrast, the Aaron-Reischauer and Ball plans tax 85 percent or more of Social Security benefits. 
The Maintain Benefits plan contains two features that Aaron-Reischauer did not choose to copy. One is a 1.6 percentage point payroll tax increase in 2045 and the other is a redirection of money currently scheduled to go to Medicare to OASDI. The later feature of the MB plan seems ill advised as the long-run finances of Medicare are in worse shape than those of OASDI. Similarly, the A-R plan contains several features not in the MB plan. These include accelerating and extending the increase in the age of normal retirement, advancing the age of early retirement, and readjusting the spousal and surviving spouse benefits. The Office of the Actuary of Social Security estimates that both plans, if enacted immediately and completely, would more than eliminate the 75-year actuarial deficit of the system.

The common feature of the two plans shown in Table 1 is that the biggest contributor to eliminating the long-run solvency problem is investing part of the OASDI Trust Fund in private securities. The two plans differ in the details of how they would do that. In fact, the Maintain Benefits plan in the 1994-96 Advisory Council Report suggests further study be given to the idea before implementation. Nonetheless, when the Advisory Council scored the plan to see whether it achieved the goal of eliminating the 75-year actuarial deficit, they included the provision that the Trust Fund would begin investing in stocks in the year 2000 and that the proportion of the Trust Fund assets in stocks would gradually rise until it reached 40 percent in 2015 . The assumed real rate of return on the stock portion of the portfolio in the Maintain Benefits plan is 7.0 percent. The Aaron-Reischauer plan is to have the trust fund balances that exceed 150 percent of one year's benefits gradually invested in common stocks and corporate bonds. Since the OASDI trust fund balances currently exceed the 150 percent of annual payout criteria, the switch to private securities would begin immediately under the A-R program. Remarkably, Aaron and Reischauer estimate that 55 percent of the whole actuarial deficit of 2.19 percent of 
payroll would be eliminated by this asset reallocation alone. They also estimate that the combination of the asset reallocation and the effect of the changes that BLS is making in the construction of the CPI eliminates over 75 percent of Social Security's projected long-term deficit. Any 75 percent cure that is this painless deserves careful scrutiny.

\section{The Net Transaction}

The net transaction involved in having the central OASDI trust fund invest a portion of its assets in common stocks is an asset swap. Social Security or the federal government sells additional government bonds to the public and uses the proceeds to acquire common stock from the public. In the Social Security context, the system is selling one set of assets (U.S. government bonds) in order to acquire another set of assets (a diversified portfolio of common stocks) of equal value. Of course, this transaction can be examined without reference to Social Security's financial problems at all. The real issue is whether the government can improve the welfare of taxpayers (or Social Security participants) by issuing and selling bonds and using the proceeds to buy common stocks.

There are at least two reasons to be skeptical about the advantages of the net transaction being discussed. First, the total capital stock and wealth in the economy (at least to a first approximation) is unaffected by the asset swap. Therefore the level of GDP and National Income is unchanged. If Social Security or the government can systematically improve its financial position by making this exchange, the private sector, which presumably is on the other side of the transaction, is systematically losing. It is hard to imagine that the politicians and bureaucrats running Social Security are systematically getting the better of the pension fund managers and institutional investors who are buying the bonds from the government in exchange for common stocks. It is possible, of course, that the exchange could be played out on 
international capital markets so that Americans as a whole could conceivably end up as net winners (or losers) in the transaction. Second, there is the matter of risk. While stocks have a much higher expected return than government bonds, they also involve much higher risks (particularly given the fact that the current special issue bonds have the feature that they can be redeemed at par at any time). The two plans discussed above are very vague as to how much additional risk the system would be assuming and how that risk would be shared among taxpayers and Social Security participants. As we will discuss in Section VI below, there is a real question about whether it is feasible to maintain a universal coverage defined benefit pension plan funded with risky securities.

Having the government exchange bonds for stocks in the hope of relieving the solvency problems of Social Security is a form of financial engineering. The recent history of such schemes is not promising. Savings and loans sell short-term liabilities (certificates of deposit and demand deposits) and acquire higher-yielding long-term mortgages. The S\&L crisis of the 1980s was brought about when short-term interest rates peaked in 1980 in the mid-teens when the S\&L mortgage portfolio yielded six to eight percentage points less. The usual yield relationship did not hold and the resulting bankruptcies and bailouts cost the taxpayers massive sums of money. The Orange County debacle resulted from a similar failed attempt to exploit the shape of the yield curve. The recent massive losses of hedge funds resulted from asset swaps that failed to perform as expected. Before the U.S. government engages in exchanging bonds for stocks, careful analysis is clearly warranted.

\section{Analyzing the Stocks for Bonds Swap}

To gauge the riskiness of the net transaction of selling government bonds and buying corporate stocks, we use market returns from 1954 to 1997 and simulate what would have 
happened if the government had completed the transaction. We separately look at what would have happened with the government selling 10 year and 20 year bonds. We assume that market returns would have been unaffected by the government transaction. This almost certainly favors the exchange strategy that in reality might very well drive up interest rates and depress equity returns. The counterfactual simulations have the government selling bonds in the past, buying the S\&P 500 stock portfolio with the proceeds, and then paying all of the bond payments (interest and principal) from the resulting stock portfolio. The strategy is deemed successful if all of the payments on the bonds can be made with the stock funds with money left over. The strategy is deemed to have been a failure if the stock portfolio is unable to generate sufficient cash to make the required bond payments. In the discussion below, we initially explore how the strategy would have worked with the actual time series of returns generated by the stock market (and the actual historical interest rates on government bonds). The interest rates are those published in the Economic Report of the President (1998) and computed by the Board of Governors of the Federal Reserve System. The stock market returns are the "Large Company Stocks" (i.e. S\&P 500) total return series in Ibbotson (1998). The problem with this historical 1954-97 approach is that there are not many independent ten or twenty year periods in our data set. In fact, there are only four completely independent ten-year runs of data and two of twenty years. We could add more data by examining pre-1954 information and we will do so in some of the analyses in this section. There is a serious question about whether adding data before 1954 helps or hurts in assessing the viability of a proposed strategy for the $21^{\text {st }}$ Century. The problem is that the additional data are likely drawn from a different regime and, therefore, may do more harm than good to the analysis. After examining the actual performance of the stock market in the 1954-97 period, we report on extensive bootstrap simulations of what could have happened 
using the same annual return data, but now with the order of the returns randomly scrambled according to a bootstrap statistical approach.

First, we examine the case of the government borrowing money for ten years at the actual historical interest rates on U.S. government bonds and investing in the S\&P 500. Figure 2 shows the money left over at the maturity of the bonds (per dollar borrowed) after all bond payments had been made out of the stock account. The net cost of the original asset swap is zero, so any residual money is a pure profit and any residual shortfall is a loss. Given our definition of success and failure, the asset swap strategy would have failed 7 times out of the 34 counterfactual experiments. The limitations of the actual historical record are very apparent in the results, however. Basically, the strategy of the government issuing ten-year bonds and

Figure 2: Net Money Generated at the Completion of a Swap of Ten-Year US Government Bonds for Common Stocks

Remaining dollars

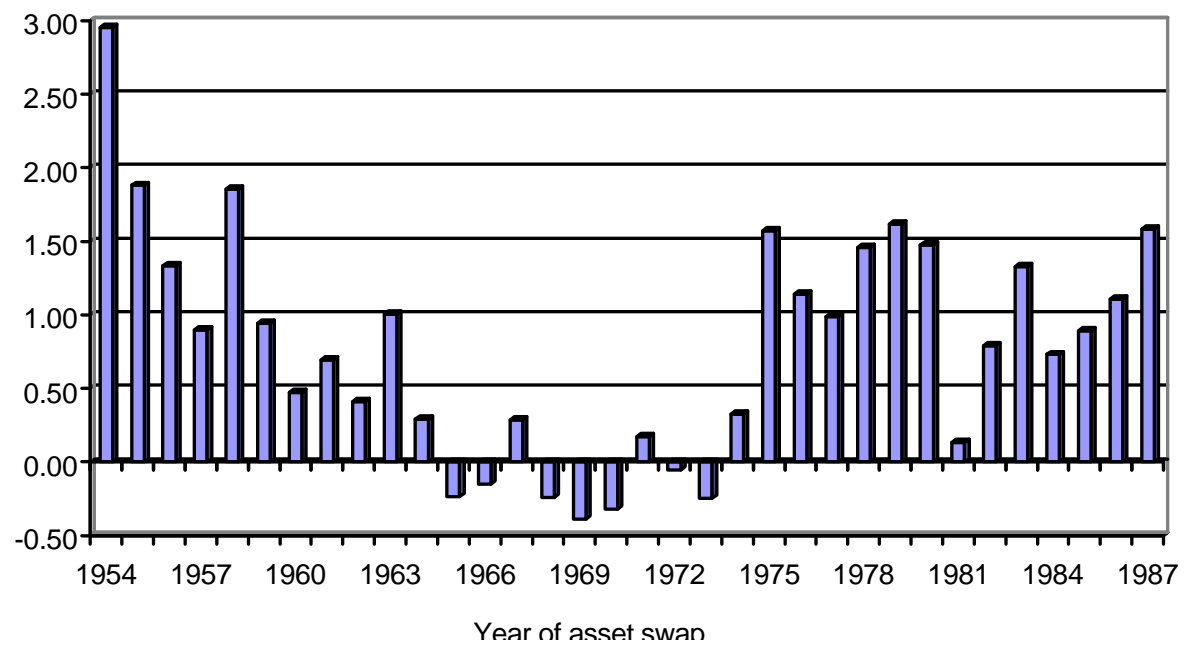


buying the S\&P500 would have worked from 1954 through 1964 and again from 1975 through 1987. However, it would have failed in 7 of the 10 years 1965 through 1974. This reflects the limitations of only observing four completely independent ten-year sets of data. On an annual basis the failure rate is 7 out of 34 or 20.6 percent, but a more informative way of reporting it is that the failure rate is roughly 1 in 4 (from the fact that we had four non-overlapping stretches of data and the strategy worked in 3 of the 4). It should also be noted that our criterion for success is very modest. We are not requiring that stocks match the 7 percent real yield assumed in scoring the Maintain Benefits plan. Rather, we are simply requiring that the stock returns were sufficient to pay off the bonds, which had low or even negative ex-post-real returns (especially in the 1970s).

While we have been focusing on the non-trivial chance of failure of the asset swap strategy, it should also be noted that Figure 2 indicates that it indeed would have worked 27 out of 34 times. Further, when it works, the average gain is quite substantial. The numbers in the figure are the amount of money left in the stock account (per dollar borrowed) at the maturity of the bonds. The overall average amount left over for the 34 experiments is 78.5 cents per dollar borrowed; the average over the 27 years with positive outcomes is almost $\$ 1.05$. Of course, it is well known that on average stocks outperform bonds by a wide margin. What is less well known is that borrowing money for ten years (even with the favorable interest rates available to the government) to buy stocks is very risky.

To acquire a better sense of how such a government asset swap policy might work in the future, we have used the same set of 1954-97 stock returns as the basis for generating simulated sequences of returns using a moving-block bootstrap method to allow for autocorrelation. For each year, 1954 through 1997, we calculate what would have happened if the government had 
borrowed additional money with ten-year bonds (at the actual prevailing interest rate). The stock market return in the year of the borrowing is taken as the actual return in that year. However, the succeeding real returns for the next nine years are randomly chosen in blocks of three-year sequences or "blocks" (with replacement) from the set of all realized real returns. For example, in order to calculate how this strategy would have worked in 1971, we compute the terms on the borrowed money according to the prevailing nominal interest rates in 1971. Further, we assume that the return on the stock market for the first year was the actually observed 1971 return. For the returns for the next nine years we randomly choose three dates (with replacement, meaning that the same date could be chosen more than once) between 1954 and 1995. If we choose 1958, 1988, and 1956, for instance, then the ten year string of real returns under this simulation would be $\left(R_{71}, R_{58}, R_{59}, R_{60}, R_{88}, R_{89}, R_{90}, R_{56}, R_{57}, R_{58}\right)$, where $R_{t}$ is the total real return of the S\&P 500 for year t. The fact that we are choosing three-year blocks of data should be apparent in this sample vector of returns. The real returns chosen via the bootstrap technique are converted into nominal returns using actual historical inflation rates. For instance, in the counter factual experiment of borrowing money in 1971, we use the actual inflation rates for 1971-80 to generate the nominal returns resulting from the real returns chosen by the bootstrap process. For each asset swap year, we examine 1,000 such random sequences of returns. ${ }^{3}$ The failure rate for the strategy differs by the year of the swap because of different interest rates and because of different first-year stock market returns. The results of this bootstrap simulation are shown in Figure 3.

Implicitly we have assumed stability in the underlying probability distribution determining real stock returns during the $1954-97$ period and that each observation was equally 
Figure 3: Failure Rate by Year of Asset Swap for 10-Year Bonds, Bootstrap Simulations with 3-Year Blocks, 1954-1988

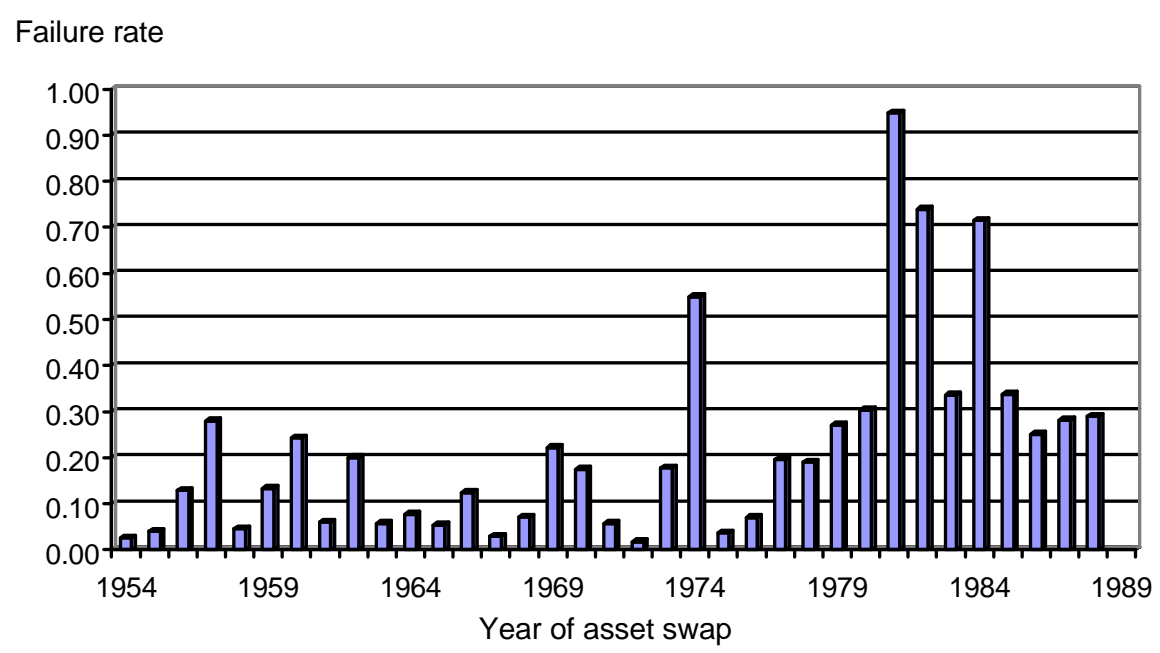

likely. Of course, it is certain that these assumptions are not entirely correct; it is also certain that many low probability events never occurred in the observation period. Finally, we are assuming that the same underlying probability distributions that generated the 1954-97 observations will generate stock market returns in the future. In total, this is a strong set of assumptions. Nonetheless, the implied results provide important insights. According to Figure 3 , the overall failure rate is predicted to be 22.1 percent, meaning that the asset swap policy failed 9,723 times in the 44,000 simulations we did for the combined 44 years of analysis. The expected failure rate for the most recent ten-year period was 44.7 percent due to the higher real interest rates of this period. Note that these failure rates are most likely conservative since they still are based on the robust returns realized in U.S. equity markets in the 1954-97 period. These failure rates may therefore form something of a lower bound on the riskiness of the asset swap strategy going forward. ${ }^{4}$ 
The pattern of failure probabilities in Figure 3 stand in sharp contrast to the success or failure patterns in Figure 2 using the actual realized time series of returns. The reasons for the divergence are easily explained. The accelerating inflation of the 1970s was not fully incorporated into government interest rates until 1981 and 1982. The ex-ante analysis of Figure 3 shows that to be the period with the highest chance of failure for the ten-year bonds for stocks swap (particularly with the poor performance of the stock market in 1981). However, ex-post the stock market has performed extraordinarily well from 1982 to the present. As a result, the asset swap strategy would have worked in 1981 and 1982, even though our bootstrap simulations show that it had a relatively low probability of doing so. On the other hand, the ex-ante failure probabilities in 1965-72 were not particularly high; nonetheless, in fact, the strategy would have failed in six of those eight years as shown in Figure 2. The point is that the returns that were actually experienced were just a single set of draws from an economic and financial system generating risky returns.

We perform the same analysis for twenty-year bonds. In this case, the limitations of the data are even more severe since there are only two completely independent sets of twenty-year observations in the 1954-97 data set. Therefore, it is difficult to know how to interpret the fact that the asset swap strategy would have worked for every year 1954-77 using actual interest rates and the actual time series of stock market returns. This says very little about the underlying chance of failure with a future policy of swapping twenty-year government bonds for a diversified portfolio of common stocks. The same bootstrap approach is used in this case as with the ten-year bonds. Now, instead of a single historical set of stock market returns, we can generate thousands of simulated sequences of returns generated from a random selection of the actual annual observations. The results of doing that are shown in Figure 4. 
Figure 4: Failure Rate by Year of Asset Swap for 20-Year Bonds, Bootstrap Simulations with 3-Year Blocks, 1954-1978

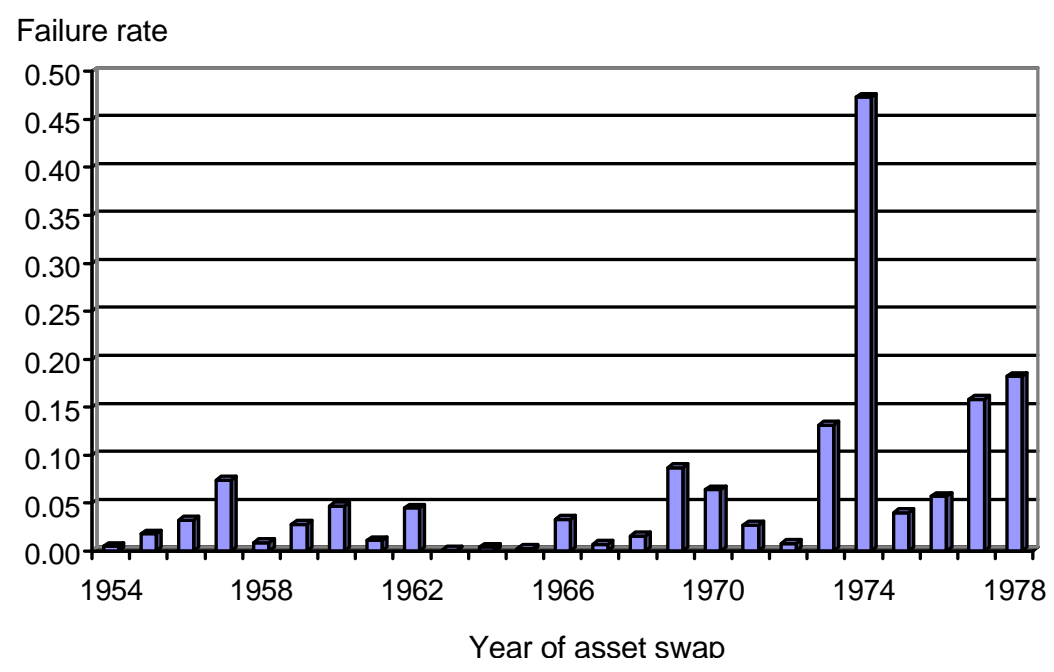

The pattern of failure probabilities is primarily determined by the actual pattern of nominal interest rates on government bonds and by the actual first-year return on the stock market. Therefore, it is not surprising that the general pattern of failure rates is similar in the twenty-year bond case of Figure 4 and the ten-year bond case of Figure 3. The high failure probability (47.3 percent) for the asset swap strategy in 1974 is due to the fact that the real return on the S\&P 500 in 1974 was -34.5 percent. If stocks lose more than one-third of their value immediately after you sell bonds to buy stocks, your chances of making the swap work are greatly diminished.

For twenty-year bonds, the overall predicted failure rate during 1954-78 is 6.24 percent. In the most recent ten-year period (1969-78) the failure rate is predicted as 12.27 percent, which we view as a considerable chance of failure. This suggests that if the government were to borrow money by issuing twenty-year government bonds (assuming it could do so 
without raising interest rates) and if the real returns on the stock market were generated by the same process that produced the returns of 1954-97 (although with the ordering of the returns randomly scrambled), the chance that the government would have to borrow additional money when the bonds mature is about one in eight. The asset swap has a considerable chance of being counter productive in terms of the finances of the federal government in general and Social Security in particular.

The historical record on interest rates also represents only a single set of realizations of what might have happened. Future real (or nominal for that matter) interest rates may be higher or lower than what we have observed in the past. To add some robustness to our results, we examine what would have happened to the finances of the government if it issued inflationindexed bonds and bought stocks with the proceeds. In our first experiment, we set the real interest rate on ten-year inflation-protected bonds at 3.5 percent. This is actually somewhat less than the recently observed interest rate on this type of security. Each year the principal on the bonds is marked up to reflect realized inflation. The bonds are assumed to pay 3.5 percent interest each year on the revised (i.e. inflation adjusted) principal amount and at maturity return the original investment marked up by cumulative inflation. The question we want to ask is how likely is it that an S\&P 500 stock portfolio can generate sufficient returns to pay off the claims of such inflation-indexed bonds?

Once again, we can look at how this asset swap would have fared historically if it could have been accomplished without affecting the actually observed stock market returns. In this case we have used the observed stock market returns and inflation rates for the period 1927-97 and examined counterfactual asset swaps for the 61 years 1927-87. Basically, we have six full 
and completely independent (i.e. non-overlapping) runs of ten-year data. Figure 5 shows the results for this case with ten-year inflation indexed bonds. The strategy would have failed 18

\section{Figure 5: Net Money Generated at the Completion of a Swap of Ten- Year Inflation-Indexed U.S. Government Bonds for Common Stocks}

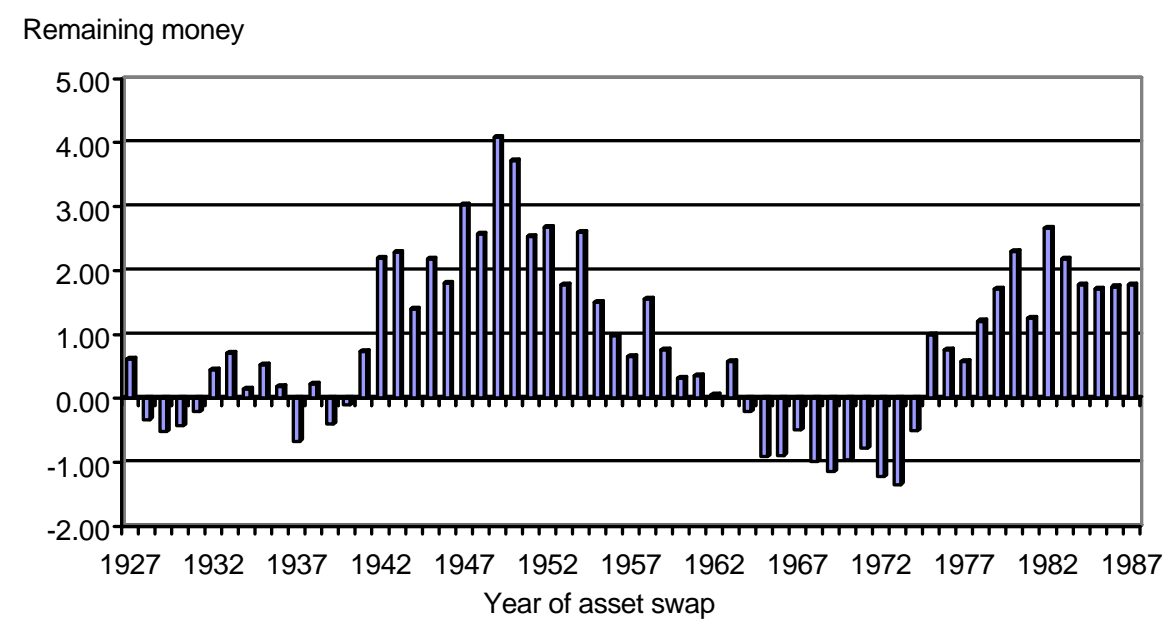

times out of the 61 years examined for a failure rate of 29.5 percent. The failures are strongly autocorrelated, however, because of the overlapping returns. If the swap strategy fails in year t, it is quite likely that it will also fail in year $t+1$ since the two experiments involve nine common years of stock market returns. Not surprisingly, Figure 5 shows that the asset swap strategy would have had mixed success in the 1927-40 period, followed by twenty-three years of complete success, followed by eleven years in a row of failure and, finally, by thirteen years of success. Some of the failures are quite substantial. In seven of the 1964-74 years the government would have had to borrow a second time an amount roughly equal to its initial issuance of bonds to be able to pay the principal of the maturing bonds. 
The autocorrelation in the success or failure of this strategy calls into question one aspect of the Maintain Benefits and Aaron-Reischauer plans that we have not yet modeled - namely that both plans advocate that the asset swaps take place continuously. Both plans would only gradually phase in the private securities investments of the OASDI Trust Fund. One could hope that some kind of "dollar-cost averaging" phenomenon would make this less risky than making the asset reallocation all at once. However, the eleven failures in a row from 1964 through 1974 indicate that considerable risk remains even with such a gradual transition. If Social Security had engaged in this particular asset swap (ten-year inflation-indexed bonds for a portfolio of the S\&P 500) from 1964 through 1974, the financial crises that the system faced in 1977 and again in 1983 would have been considerably worsened.

We have also simulated how the asset swap of ten-year inflation-indexed bonds for common stocks would perform in the future if future returns and inflation rates were drawn from the 1927-97 set of realizations drawn randomly with a bootstrap technique. The predicted overall failure rate was 29 percent. That is, the stock portfolio failed to generate the necessary 3.5 percent real return required to pay-off the obligations of the inflation-indexed bonds 29 percent of the time. If we had defined failure as the stock investments falling short of the seven percent real rate of return assumed in scoring the MB plan in Table 1, the failure rate would, of course, be much higher.

The results for twenty-year inflation-indexed bonds are similar. Figure 6 shows the counterfactual history for asset swaps from 1927 through 1977. The strategy would have failed 18 times out of the 51 years for a failure rate of 35.3 percent. Even more telling is the fact that it would have failed fifteen years in a row from 1959-73. The strategy is very successful from 1932 through 1954 and again in 1975-77. This is not surprising since we know that the average 
real return on the stock market in 1927-97 has been well above 3.5 percent. The failure or limited success of the strategy for twenty years in a row (1955-74), however, is a big problem for its advocates. The overall failure rate when the 1927-97 inflation rates and stock market returns are scrambled with a bootstrap technique of choosing the observations is 25.4 percent.

\section{Figure 6: Net Money Generated at the Completion of a Swap of 20-Year Inflation-Indexed U.S. Government Bonds for Common Stocks}

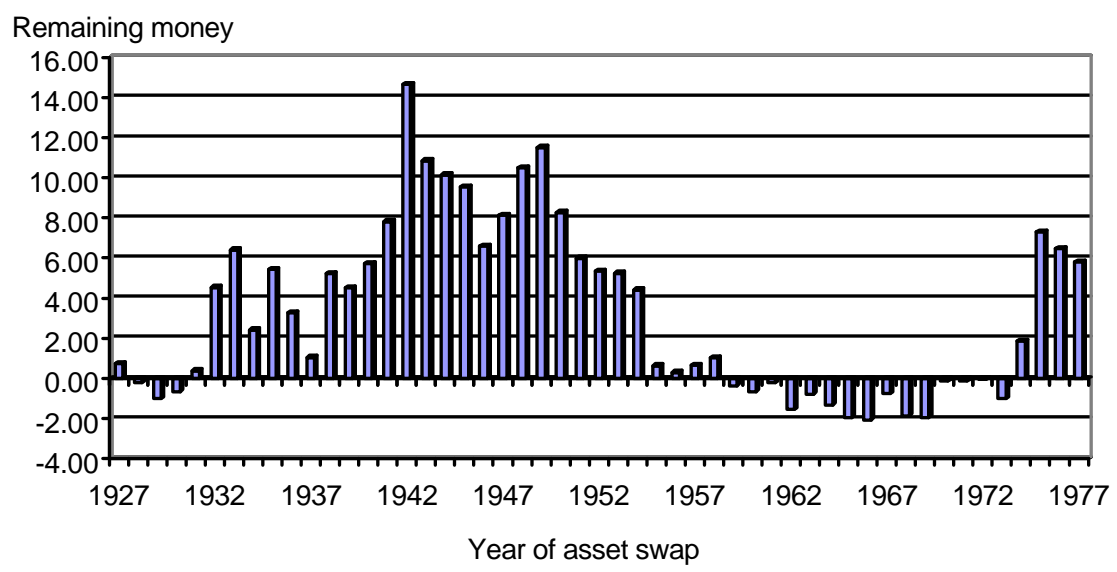

Table 2 sums up what we have learned thus far. We have examined a total of four different cases for asset swaps based on ten-year bonds and the same four cases for twenty-year bonds. The bootstrap simulations are probably more informative regarding the future chances of success for the exchange than the numbers based on the actual historical time series of returns.

Table 2: Summary of Failure Rates of A Strategy of Swapping Bonds for S\&P 500 Stocks

\begin{tabular}{|c|c|c|c|c|}
\hline $\begin{array}{c}\text { Bond } \\
\text { Maturity }\end{array}$ & $\begin{array}{c}\text { Actual Interest Rates; } \\
\text { Actual 1954-97 Time } \\
\text { Series of Stock } \\
\text { Market Returns }\end{array}$ & $\begin{array}{c}\text { Actual Interest Rates; } \\
\text { Bootstrap Simulations of } \\
\text { Real Returns Chosen from } \\
\text { 1954-97 Realizations }\end{array}$ & $\begin{array}{c}\text { 3.5\% Inflation-Indexed } \\
\text { Bonds; Actual 1927-97 } \\
\text { Time Series of Inflation } \\
\text { and Stock Market Returns }\end{array}$ & $\begin{array}{c}\text { 3.5\% Inflation-Indexed } \\
\text { Bonds; Bootstrap Simulations } \\
\text { of Real Returns Chosen from } \\
1927-97 \text { Realizations }\end{array}$ \\
\hline 10 Years & $20.6 \%$ & $22.1 \%$ & $29.5 \%$ & $29.0 \%$ \\
\hline 20 Years & $0 \%$ & $6.2 \%$ & $35.3 \%$ & $25.4 \%$ \\
\hline
\end{tabular}


That is because the future will not be a precise replay of the past. The bootstrap simulation technique gives us a better handle on the probability of future success. If real stock market returns are generated in the future from the same distribution which generated the actual 1954-97 returns and if real interest rates on bonds approximate 3.5 percent, then the failure rate of a strategy of swapping bonds for stocks is about 29 percent for ten-year bonds and 25 percent for twenty-year bonds. These figures refer to the final column of results in Table 2. It is important to note, however, that all variations of the asset swap simulations that we have done imply a considerable risk of failure.

\section{Tax Considerations}

We have ignored personal income tax issues thus far, but they deserve some consideration. The federal government collects taxes on the returns of stocks held in private hands and would recapture some of the interest payments on the bonds through tax proceeds. If the average marginal tax rate on the returns is the same for the stocks and bonds, then it is a fairly minor correction to the above results. For instance, assume that on the "other side" of the transaction are defined contribution pension funds. Further, assume that as people see that the Social Security Trust Fund is moving out of bonds and into stocks they are willing to move in the opposite direction in their own IRA, 401(k), or other DC accounts (without a change in interest rates). If the average marginal tax rate of the pension plan holders will be 25 percent when the money is drawn out, then the government effectively owns one-fourth of the assets in the plan. If the government makes money on the swap on its own account, it loses one-fourth of its profits due to its participation in the DC accounts (which took the other side of the asset swap) via the tax system. The failure rate analysis of the previous section need not be modified, although the 
absolute size of the gains and losses is reduced by 25 percent. If the other side of the transaction consisted of corporate accounts backing DB pension promises, then the gain or loss in the funding of the pension plan presumably would be reflected in the stock of the corporation offering the DB plan. Stockholders will eventually pay capital gains taxes on their stock (sooner rather than later if the stocks are held by an actively managed mutual fund), and once again the government will find itself with roughly a twenty or twenty-five percent position on the opposite side of the swap that it thought it was engaged in. Also, once again, the failure rate analysis of the previous section is unaffected.

We think that pensions are the most likely "other side" of the asset swap transaction. We have also examined the case where privately held assets are exchanged with the government. If the average marginal tax rate on the interest payments of the government exceeds the blended average marginal tax rate faced by dividends, and short and long-term capital gains from the stock returns, then the failure probabilities are slightly improved by tax considerations. The government recaptures a higher percentage of its interest payments through the tax system than it did on the return on common stocks. The effect is fairly minor, however. We probably were exploring the upper limit of the effect in assuming that the average marginal income tax rate on interest on the bonds was 33 percent whereas the average marginal tax rate on long-term capital gains was 20 percent. Both numbers are almost certainly on the high side, but the difference may be reasonable. With such parameters the projected failure rate of issuing fixed interest rate ten-year bonds turns out to be 25.1 percent. The twenty-year bond failure rate falls from 6.2 percent to 5.4 percent. The failure rate for ten-year bonds remains 21.1 percent even if somehow the stocks had paid zero taxes and the bonds faced an average marginal tax rate of 33 percent. The worst case for the government is the opposite of that, of course. If the bonds are somehow 
held in completely tax-free accounts whereas the stocks had been fully taxable ( 33 percent on dividends and short-term capital gains and 20 percent on long-term capital gains), then the predicted failure rate with ten-year fixed interest bonds jumps to 37.9 percent.

Our conclusion regarding taxes is that they are an important second-order consideration, but that the results of the previous section - that the government issuing bonds and using the proceeds to buy stocks - is very risky is not materially altered by including the effects of taxes.

\section{Interpretation of Failure Results}

We feel that the most appropriate of our asset swap simulations in terms of predicting the likelihood of future failure of such a policy are those which use the 3.5 percent real interest rate inflation-protected bonds and generate real stock returns with the bootstrap procedure. These results are relevant even if the government actually swaps nominal bonds for stocks, because the real interest cost of such bonds is far more likely to approximate 3.5 percent than the negative real interest rates which prevailed in the 1970s. The result is that the asset swap strategy has about a 25 percent chance of failure with twenty-year bonds. This means that there is a 25 percent chance that the switch into stocks will make the solvency problems of Social Security worse rather than better after twenty years. Of course, there is about a 50 percent chance that the strategy will not work as well as assumed by its proponents (and listed in Table 1). That is because the 7 percent real rate of return assumed in that table is roughly the median long-run real rate of return for stocks.

Someone might take the view that if stocks are behind after twenty years, the government can simply borrow the shortfall (or more) and buy yet more stocks. With a long enough time horizon, stocks are bound to beat out bonds, right? First, this is not quite right. It is true that the 
probability of a shortfall is lower the longer the time horizon. Of course, the magnitude of the shortfall in the unlikely event that stocks have a bad forty or fifty year run can be enormous if each intermediate shortfall is covered with more borrowed money. Second, and probably more importantly, the balance sheet position of Social Security is economically and politically important. The Social Security crises of 1977 and 1983 were caused by the fact the impending exhaustion of the OASI Trust Fund. Of course, the government could have bailed out the fund by borrowing money and handing it over to Social Security. But that action was not seriously considered. Our point is that the Trust Fund would have been in even worse shape in the late 1970s and early 1980s if it had been investing in stocks in the 1960s instead of the special issue Treasury Bonds. In that case, the benefit cuts and tax increases would have been even more severe than they were. One would not have been able to get through that period with the argument that we can just borrow more money and buy more stocks and sooner or later the strategy will pay off. The extra risks of stocks translate directly into riskier future benefits and taxes.

The failure probabilities that we have estimated are only as good as the modeling of the underlying process generating real stock market returns. In a number of respects we have erred on the side of favoring the strategy. First, we have assumed that the government could engage in the swap without changing interest rates and stock market rates of return. Second, we have assumed that future stock market returns will be generated from the observed returns from 195497 (1927-97 in some cases). The average real rate of return on stocks from 1954-97 was 9.7 percent. The average from 1927-97 was 9.6 percent. Still, relative to either international comparisons or longer historical returns (Siegel(1994)), these average returns are quite high. 
For most of the results that we have presented, we have worked with three-year blocks of stock market returns. We have assumed that each of the three-year blocks observed from 195497 is equally likely to be repeated, independent of the previous returns drawn. There is a literature on long-run mean reversion which indicates that high returns are more likely to follow low returns (and vice versa)(see, for example, Poterba and Summers(1988), Fama and French(1988), and chapter 2 of Campbell, Lo and MacKinlay(1997)). If this were true, then long horizon investing would be safer than if returns were drawn independently from previous realizations. The statistical evidence on long-run mean reversion is not very powerful for the same reason that we have had to downplay our actual counterfactual results - there simply are not many long runs to observe in order to investigate such long-run phenomena. The empirical studies that have been done cannot rule out that returns are actually serially independent. With that said, all we can say is that if returns were generated by a process exhibiting long-run mean reversion, then the asset swap strategy would fail less often than we have estimated. Our simulations of the asset swap strategy using one, two, three and five year blocks of data showed roughly the same failure probabilities. This indicates that mean reversion, to the extent it operates in less than five years, is at most a relatively weak phenomenon.

Our overall conclusion is that the simplifications in this study have not biased the results against the asset swap policy. The relatively high mean return that we assume for equities must be at least as important an assumption as the lack of mean reversion in returns over periods greater than three years. If asked the likelihood that investing some of the central trust fund of Social Security in equities would worsen its finances in ten or twenty years, our best guess answer would be that there is a 25 to 30 percent chance. 


\section{Is a Universal Defined Benefit Retirement Plan Feasible?}

Our conclusion thus far has the usual "no-free-lunch" ring to it. Unfortunately, one cannot eliminate the actuarial deficit of Social Security by swapping bonds for stocks. If it were possible, then we would also do well to eliminate the cost of the defense budget with the same maneuver. This raises the question of who bears the risks in the current Social Security system and who would bear the additional risks if the trust fund were to invest in private securities as advocated by the Maintain Benefits plan and the Aaron-Reischauer plan. Even more fundamentally, it raises the issue of whether it is feasible for the government to offer a defined benefit plan with universal coverage.

At one extreme, consider a defined benefit plan offered by a financially strong company such as General Motors. The company can promise its workers a particular or "defined" benefit in retirement and fund that obligation with private stocks and bonds. The worker can accumulate a vested, safe retirement benefit (although not safe from the effects of inflation) while the firm, or more accurately its stockholders, bear the investment risks of the underlying portfolio. The point is that it is quite transparent how a safe benefit was created from risky investments - the risky residual claim is borne by the General Motors stockholders.

At the other extreme, consider what would happen if a self-employed person decided that he would like to provide himself a defined benefit pension funded with stocks and bonds. Is it feasible? Can a person invest, say, $\$ 30,000$ in stocks and bonds and promise himself or herself a safe retirement benefit of $\$ 3,000$ per year? The answer is "no" since the employer bears the risk of the assets not being adequate to fund the benefits. But a self-employed person is both employee and employer. The investment risks have not been transferred at all and, therefore, the do-it-yourself DB strategy cannot work. The only way for a self-employed person to end up with 
a defined benefit-like retirement claim is for them to contract with an insurance company or other third party which will provide the benefit and assume the investment risks.

Now consider a universal coverage defined benefit Social Security retirement pension system funded with risky private securities. Is it possible to provide safe retirement benefits as in the General Motors example or is it more like the example of the self-employed person who cannot make meaningful retirement benefit promises without the help of a third party? If everyone is in the Social Security system, then collectively everyone bears the investment risk and it makes little sense to call the program a defined benefit scheme. There are only two ways that we can think of to maintain the defined benefit nature of the system. One is to divide the population by age cohort. Conceivably the elderly can be promised safe benefits with the young playing the role of the insurance company and bearing the investment risks of the underlying portfolio. The future payroll taxes or the future benefits of the young will be more risky if the Trust Fund engages in the kind of asset swap we have been analyzing. One of the drawbacks of a defined benefit structure is that the risks imposed upon the young are not very transparent. If we maintain the defined benefits for both the old and the young, then the taxes faced by the young will be even more volatile. The point is simply that the considerable risks involved in investing in private securities, which we have documented above, have to be borne by someone. The defined benefit nature of the system does not work very well if the investment risks are borne by personal income taxpayers. The reason is that there is nearly a complete overlap between Social Security participants and personal income taxpayers. In order to create a safe asset from a risky portfolio, the risks have to be shifted to someone other than the holder of the supposedly safe claim. Shifting the risks from Social Security participants to taxpayers is not enough of a shift to accomplish this. 
At least conceptually, the investment risks could be shifted internationally. Shiller (1998) makes this point in his theoretical paper on risks and Social Security. The Europeans, for instance, could play the role of the insurance company and offer Americans a safe defined benefit pension system by assuming the investment risks themselves. There is a question of what terms they would demand to hold all of the risks. Further, while it is clear that there are advantages of the young and old and the Europeans and Americans all sharing in the risks of global financial markets, it is not at all clear why one group (the young or the Europeans) should hold all of the risk so that another group (the elderly Americans) can enjoy a safe, defined benefit retirement program. The optimal risk-sharing arrangement would have everyone bearing some risk and, thus, any optimal universal pension plan would not be strictly of a defined benefit type.

One problem with investing the central OASDI Trust Fund in private securities that we have not emphasized is the danger that the investment decisions would be subject to political pressures and, therefore, would not manage risk efficiently. There would undoubtedly be pressure to invest in only American companies or only unionized companies or to allocate the investments evenly across the fifty states or not to invest in tobacco companies or those doing business in Burma. Aaron and Reischauer are confident that certain organizational structures that they propose (including the creation of a "Social Security Reserve Board") could insulate fund management from political control by elected officials. We are not so sure. It is quite possible that capital would be less efficiently allocated with government ownership of equities meaning that the asset swap could reduce aggregate future GDP. 


\section{Conclusions}

In this paper we have examined the risk of having the central OASDI Trust Fund invest in private securities. We have noted that net transaction is an asset swap with the government selling bonds to the public and using the proceeds to buy a portfolio of common stocks of equal value. The asset reallocation does not increase saving, wealth, or GDP. We examine whether it actually would improve the finances of the Social Security system. We adopt a convention that the asset swap is deemed successful if the stock portfolio generates sufficient cash to pay off the interest and principal of the bonds and still have money left over. The swap is a failure if the stock portfolio is insufficient to do that and the bond repayments require another round of borrowing. We have looked at several cases including ten-year and twenty-year fixed interest rate bonds and ten and twenty-year inflation-indexed debt. The predicted failure rate from the bootstrap simulations of future returns range from 6 to 29 percent. Further, failure would be autocorrelated with long strings of annual failures possible. For instance, when we examined the counterfactual issuance of twenty-year inflation indexed bonds we found that the asset swap strategy failed fifteen years in a row between 1959 and 1973. Clearly, this policy cannot reliably reduce the actuarial deficit of Social Security.

Individual accounts and defined contribution pension plans certainly involve significant risks. An individual who shifts from bonds to stocks runs the same or greater risk that the move will be counterproductive after ten or twenty years. However, the defined contribution plans have the advantage that their risks are rather straightforward. Further, people who want to minimize risks can invest in safe assets such as inflation-indexed bonds. The analysis of this paper has shown that an OASDI Trust Fund invested in private securities would generate risk for Americans, but the precise incidence of that risk would likely remain ambiguous. 


\section{References}

Aaron, Henry J. and Robert D. Reischauer, Countdown to Reform: The Great Social Security Debate, The Century Foundation Press, New York, 1998.

Campbell, John Y., Andrew W. Lo and A. Craig MacKinlay, The Econometrics of Financial Markets, Princeton University Press, Princeton, New Jersey, 1997.

Economic Report of the President: 1998, U.S. Government Printing Office, Washington, D.C., 1998.

Fama, Eugene F. and Kenneth R. French, "Permanent and Temporary Components of Stock Prices, Journal of Political Economy, volume 96, no. 2, 1988, pp. 246-73.

Goss, Stephen, "Measuring Solvency in the Social Security System," in Olivia Mitchell, Robert J. Myers, and Howard Young, eds., Prospects for Social Security Reform, The University of Pennsylvania Press, Philadelphia, Chapter 2, 1999.

Ibbotson Associates, Stocks, Bonds, Bills and Inflation: 1998 Yearbook, Market Results for 1926-97, Ibbotson Associates, Chicago, 1998.

MaCurdy, Thomas E. and John B. Shoven, "Stocks, Bonds, and Pension Wealth," in Topics in the Economics of Aging, David A. Wise, ed., National Bureau of Economic Research, The University of Chicago Press, Chicago, 1992.

Poberba, James M. and Lawrence H. Summers, "Mean Reversion in Stock Prices," Journal of Financial Economics, volume 22, 1998, pp. 27-59.

Schieber, Sylvester J. and John B. Shoven, The Real Deal: The History and Future of Social Security, Yale University Press, New Haven, 1999.

Shiller, Robert J., "Social Security and Institutions for Intergenerational, Intragenerational, and International Risk Sharing,” NBER Working Paper No. 6641, July 1998.

Siegel, Jeremy J., Stocks for the Long Run, Richard D. Irwin, Inc., Chicago, 1994.

Social Security Administration, Report of the 1994-96 Advisory Council on Social Security, Volume I: Findings and Recommendations, Washington, DC, 1997.

Social Security Administration, Annual Report of the Board of Trustees of the Federal Old-Age and Survivors Insurance and Disability Insurance Trust Funds, US Government Printing Office, various years.

\footnotetext{
${ }^{1}$ Our paper investigated the effects of defined contribution accumulators consistently acquiring stocks or bonds for
} careers between 1926 and 1989. We showed that stock accumulators consistently ended up with more money than 
bond accumulators for all careers longer than twenty years in the 1926-89 period. The result is weakened by the fact that we only used the actual historical pattern of financial returns and that there are only three completely independent twenty year runs of data in the 1926-89 period. We extended the data to 1876-1990 in an unpublished manuscript. There we found that the career length had to be forty years before stock accumulators always ended up ahead of bond accumulators. Once again, the data limitations do not allow one to confidently predict the likelihood of stocks outperforming bonds for long careers. In the present paper, we try to get around the data limitations by using the bootstrap statistical procedures.

${ }^{2}$ Many wage contracts are officially or unofficially tied to the CPI. It is not clear that the Office of the Actuary took the feedback of changing the official CPI on wages into account. If not, the gain from the restructuring of the CPI may be exaggerated.

${ }^{3}$ Our preliminary analysis indicates that selecting block sizes $1,2,3$, and 5 would not change the main findings reported here.

${ }^{4}$ Once again, we are concentrating on the failure probability as a measure of the riskiness of the asset swap. The asset swap does work more than fifty percent of the time and often generates large profits. 